- RESEARCH ARTICLE -

\title{
VOLATILITY SPILLOVER BETWEEN BIST 30 FUTURES AND SPOT MARKETS: A DCC-GARCH ANALYSES ${ }^{1}$
}

\author{
Esen $\mathrm{KARA}^{2} \& A$ dem $A N B A R^{3} \&$ Özer $A R A B A C I^{4}$
}

\begin{abstract}
Investors should be aware of the information flow across the markets to develop investment policies. The volatility spillover relationships between spot and futures markets includes significant knowledge for the composition of optimal portfolios. In the present study, the relationship between spot and futures markets in Turkey was investigated based on BIST 30 index end-of-day price data for the period between February 2, 2006, and April 30, 2020.

The volatility spillover effects and the time-varying dynamic conditional relationships between the markets were investigated with the DCC-GARCH model. The findings reveal the existence of a two-way volatility spillover between markets and a strong dependency between markets' return volatilities. In addition, the effect of negative and positive shocks on market volatility was analyzed with the GJR-GARCH model and the results demonstrated that both markets responded strongly to negative shocks when compared to positive shocks.
\end{abstract}

Keywords: Futures Market, Spot Markets, Volatility Spillover, BIST 30 Index, DCC-GARCH Model.

JEL Codes: $G 10, C 10$.

Başvuru: 17.11.2020 Kabul: 05.11.2021

\section{BIST 30 VADELİ İŞLEM ve SPOT PIYASALARI ARASINDA VOLATILITE YAYILIMI İLIŞKISII: DCC-GARCH ANALIZi ${ }^{5}$}

$\ddot{O} z$

Yatırım politikalarını piyasalara gelen bilgi akışı doğrultusunda hazırlayabilmek yatırımcılar için son derece önemli bir olgudur. Optimal portföy oluşturma anlamında, spot ve vadeli işlem piyasaları arasındaki volatilite yayılımı ilişkisi önem taşıyan konulardan bir tanesidir. Bu çalışmada, BIST 30 endeksi için spot ve vadeli işlem piyasaları arasındaki volatilite

\footnotetext{
${ }^{1}$ Bu çalışma Doç. Dr. Adem ANBAR'ın danışmanlığında yürütülen Esen Kara'nın 'Vadeli İşlem Piyasaları ve Spot Piyasalarda Fiyat Keşfi ve Volatilite Yayılımı: Borsa İstanbul'da Bir Uygulama' başlıklı doktora tezinden üretilmiştir.

${ }^{2}$ Dr. Öğr. Üyesi, Bursa Uludağ Üniversitesi İIBF İşletme Bölümü, Bursa TÜRKIYYE, esencimilli@ uludag.edu.tr, https://orcid.org/0000-0002-5156-4653

${ }^{3}$ Prof. Dr., Bursa Uludağ Üniversitesi İIBF İşletme Bölümü, Bursa TÜRKIYYE, aadem@uludag.edu.tr, https://orcid.org/ 0000-0001-8909-6851

${ }^{4}$ Prof. Dr., Bursa Uludağ Üniversitesi İIBF Ekonometri Bölümü, Bursa TÜRKIYYE, ozerarabaci@ uludag.edu.tr, https://orcid.org 0000-0002-5434-2458

${ }^{5}$ Genişletilmiş Türkçe Özet, çalışmanın sonunda yer almaktadır.
} 
yayılımı ilişkisi, 2 Şubat 2006 - 30 Nisan 2020 dönemine ilişkin gün sonu fiyatları kullanılarak araştırılmıştır.

Çalışmada piyasa getiri volatiliteleri arasındaki yayılım ve dinamik koşullu korelasyon ilişkisi DCC-GARCH yöntemi kullanilarak analiz edilmiştir. Elde edilen bulgular, piyalara ait volatilite değiş̧imleri arasında karşılıklı bir nedensellik ilişkisinin varlığını ve söz konusu değişkenler arasında güçlü bir bağımlılığın olduğunu ortaya koymaktadır. Ayrıca, negatif ve pozitif şokların piyasa volatiliteleri üzerindeki etkisi GJR-GARCH modeli ile analiz edilmiş ve söz konusu piyasaların kendilerine ait negatif şoklara, pozitif şoklara kiyasla daha yüksek bir tepki verdiği sonucuna ulaşılmıştır.

Anahtar Kelimeler: Vadeli Ișlem Piyasaları, Spot Piyasalar, Volatilite Yayılımı, BIST 30 Endeksi, DCC-GARCH Modeli.

JEL Kodları: $G 10, C 10$.

"Bu çalışma Araştırma ve Yayın Etiğine uygun olarak hazırlanmıştır”.

\section{INTRODUCTION}

The main function of derivatives is to provide certain financial instruments to protect individuals and institutions against adverse price movements (Karabiyık \& Anbar, 2010: 342). A n investor could employ derivatives to avoid asset price risks by selecting a derivative contract drawn for the specific asset or another closely associated asset (Chambers, 2008: 154). Derivative contracts could be drawn for spot market instruments such as commodities, stocks, bonds, and indices (Chance \& Brooks, 2013: 13). Thus, due to the increase in uncertainty in financial markets and fluctuations in asset prices, the derivative markets exhibited a rapid global expansion, and spot markets became a significant topic of discussion in finance. It was reported that volatility spillover was a factor in the relationship between derivatives and spot markets (Çelik, 2012: 9).

Volatility, which reflects significant changes in the value or price of any variable when compared to a certain average, is a frequently discussed concept in financial markets in recent years. In general, the magnitude and frequency of the fluctuations in the value or price of any financial asset is called volatility (Özden, 2008: 340). Volatility could be broadly described with the concepts of being volatile or unstable. In other words, volatility could be described as the fluctuations in a variable in the presence of certain factors. Thus, it could be suggested that the higher the fluctuations, the higher the volatility of a variable over a certain period (Daly, 2008: 2378). The phenomenon of volatility could be observed in stocks, market indexes, exchange rates, and especially inflation in developing countries. Stock prices are important in financial markets since they broker the needs of individuals or institutions who are in need of liquidity and those with excess liquidity. Because the stock price volatility could disrupt the financial system and negatively affect the economic performance. Thus, financial market volatility focuses on the stock market (A kay $\&$ Nargeleçekenler, 2006: 7). 
Stock market volatility, which reflects the ups and downs in stock prices or stock market indices in a certain period, is a common phenomenon in stock markets, and it indicates unpredictable variations in stock prices (IMF, 2003: 62; Sadiq et.al., 2013: 426). Stock markets have an important role in sustainable economic development, promoting capital formation and economic growth (Imegi, 2014: 80). However, stock market volatility may also pose a problem especially in emerging economies where high volatility in prices could lead to market capital erosion (Ghufran, A wan, K hakwani \& Qureshi, 2016: 1).

V olatility is a common phenomenon in stock markets and measures unpredictable variations in stock prices. Based on the approach that stock price volatility is a measure of the new data arrival rate, the real asset value is expected to change with the introduction of new information and its transmission to the market. Investors, brokers, academicians and regulators are interested in volatility not only because it is a measure of risk and affects the corporate value, but also the variations in prices reflect important news about the corporations (Sadiq et. al., 2013: 426). Thus, asset price volatility, although inevitable, is not an absolutely undesirable phenomenon. Because volatility reflects the pricing and risk transfer processes that arise as conditions change. In fact, when financial markets do not respond to changing conditions (e.g., policy changes or shocks), this could lead to financial resource misappropriation. However, volatility induced financial instability could also lead to certain costs. Furthermore, a sudden increase in volatility would pose a greater threat to financial stability when compared to sustained high volatility. This indicates that policy makers and market players should focus on the reduction of instability, characterized by an unexpectedly strong increase in volatility, rather than controlling the overall volatility (IM F, 2003; 426).

The recent global increase in stock price volatility led to an increasing number of studies on the factors that fed price variations and volatility (Imegi, 2014: 81). It was reported that stock price volatility could occur due to variations in company value induced by certain movements in macroeconomic indicators that could affect corporate value. Thus, an increase in stock price volatility could be the result of increased volatility in these macroeconomic factors (Hamilton \& Gang, 1996). Furthermore, it was also argued that several factors such as cyclical status of the economy, financial crises, financial liberalization, political uncertainties, and transaction volume could have positive or negative effects on stock market volatility (Schwert, 1989; Nelson, 1996; Kassimatis, 2002: 389; Wang \& Lin, 2008: 545; James \& K aroglou, 2010: 477; Imegi, 2014: 81-82; Ching \& Hsieh, 2014: 219; Pak, K im, Song \& K im, 2015: 145; Danielsson, Valenzuela \& Zer, 2016; Mathy, 2016: 167; Gulia, 2016: 96). However, there are also company-specific factors that affect stock prices such as corporate performance, changes in board of directors, appointment of new management, dividends, earnings per share, and expected returns (Imegi, 2014: 81; K urz, J in \& M otolese, 2005).

Furthermore, there could also be a relationship between volatility of the markets in the presence of a correlation between derivatives and spot market prices (Imegi,2014: 81; K urz, Jin \& M otolese, 2005). Due to the rapid growth in futures markets, the impact of derivative 
instruments on spot market volatility has been constantly investigated (B haumik, K aranasos \& Kartsaklas; 2016: 24-25). As is known, futures markets and underlying spot markets are closely associated via the arbitrage process. However, in the theoretical literature, there are two main views on the effect of the initiation of futures transactions on the volatility of the underlying spot market. Based on the first approach, the initiation of derivative transactions has a positive effect on spot market volatility, since the derivative products are the most effective tool for risk-averse investors to transfer the associated risks to other investors, and the undertaking of the risk by more informed investors reduces volatility (Bhamra \& Uppal, 2009: 2303-2304). Furthermore, futures markets have a balancing effect on the underlying spot market, since futures transactions improve the price discovery process, which reflects statistically significant employment of historical returns in one market to predict the future returns in another, improving market efficiency, market depth, and information flow. Futures market players are more informed when compared to spot market customers, and futures prices transfer knowledge to the relatively less informed spot market partakers. This leads to a stabilizing effect in the spot market (Cox, 1976; Danthine, 1978; Danthine, 1978; Hiraki, M aberly \& Takezawa, 1995; B ohl, Diesteldorf \& Siklos, 2015: 210).

Based on the second view, national economic growth increases the number of financial investment instruments, and globalization increases the interaction between the markets. Thus, the initiation of derivative transactions has an upward effect on spot market volatility. Researchers advocating this view argue that futures trading has made the underlying spot market unstable and increased the spot market volatility due to the influence of uninformed investors. Thus, uninformed investors attracted by relatively low transaction costs, high leverages, and short-selling opportunities cause noise in discovery price and reduce the information contained in the price. This leads to an increase in spot market volatility (Cox, 1976; Danthine, 1978; Danthine, 1978; Hiraki, M aberly \& Takezawa, 1995; B ohl, Diesteldorf \& Siklos, 2015: 210).

In addition to the impact of the initiation of futures market transactions on the underlying spot market volatility, another subject examined in parallel with this issue is the mutual volatility interaction or in other words, the volatility spillover between markets. Volatility spillover is the spillover of the volatility shocks in a particular market to the volatility of another market in the subsequent trading period. (Sakthivel \& Kamaiah, 2010: 82). V olatility spillover is important for studies on knowledge transfer between the markets and acts as a source of information that investors react to, leading to new expectations about risks and revenues. In other words, the investigation of the volatility spillover between markets is also a method to research informational activity in markets. Thus, it could be suggested that the market as the source of volatility also affects knowledge (Gök \& Kalayc1, 2014: 110). When a futures market possesses effective knowledge, spot price volatility would change as the flow of information from the futures market increases. In other words, if the futures market provides knowledge transfer, it would lead to the spread of volatility to the spot market. When the spot market is more efficient in the transfer of knowledge, then volatility spillover would occur from the spot market to the futures market. In summary, the increase in the flow of information to a market would increase the volatility in the market, and volatility would spread to other associated markets due to the arbitrage mechanism (Malhotra \& Sharma., 2016: 134). The main characteristic of volatility spillover is the rapid transfer of information 
between the markets and successive changes in (short-term) return volatility (Bose, 2007: 158).

Futures contracts are among the most important tools employed to protect investors against stock market risks. In addition to the hedging and price discovery functions, futures contracts are important components of investor portfolios and contribute to the market growth due to their effects on asset allocation efficiency. In this respect, according to the view that the futures market balances the spot market, futures trading will be able to improve the quality of information and increase price efficiency; thus reduce the spot market volatility to a certain degree. However, the alternative view that the futures market destabilizes the spot market also claims that uninformed investors may potentially cause noise in the futures market, which indirectly leads to an increase in the spot price volatility (X ie \& Huang, 2014: 167). The increase in spot price volatility due to futures transactions would be reflected in the flow of information created by several futures market players. The fact that the futures market plays a leading role in the information transfer process would lead to the spread of volatility from the futures market to the spot market. In contrast, when the spot market is more efficient in information transfer, volatility spillover would take place from the spot market to the futures market (M alhotra \& Sharma, 2016: 134).

A lso, the impact of speculation should be emphasized on the volatility spillover between spot and futures markets. Theoretically, two opposing views were argued on the effects of futures transactions on spot price volatility. The first approach posits that speculative transactions would reduce spot market volatility. The proponents of the view argued that spot market players could protect their positions against risks only due to the additional liquidity induced by the speculators in the futures market. Further liquidity in the futures market would reduce trading costs when buyers and sellers could buy and sell continuously in the futures market for a reasonable cost. In the lack of liquidity, market participants would encounter high transaction costs. In other words, the liquidity in the futures market protects the market participants, who are the actual owners of the commodity or the financial asset, against the negative price movements (Sakthivel $\&$ K amaiah, 2010: 82; M al hotra \& Sharma., 2016: 134).

As is known, speculators who aim for higher profits in futures markets assume the risks transferred by those who avoid the risks. Thus, spot price volatility may decrease due to the transfer of risks between the investors with different objectives. Because this would eliminate risk premiums in spot prices. Speculation in futures would not have a negative impact on spot market stability when speculators are well informed. The purchases of these investors would increase the prices when the prices are low and would decrease the prices when the prices are high. As a result of these transactions, the prices would be balanced. Thus, it was suggested that profitable speculative transactions reduce spot market volatility. According to the alternative view, the existence of speculators without adequate knowledge may lead to herd behavior, increasing market volatility. Speculators could manipulate and influence futures prices by trading large volumes in futures markets. Furthermore, price variations that lead to high volatility are communicated to the spot market through the arbitrage mechanism. Therefore, futures trading would aggravate spot market volatility. (Sakthivel \& Kamaiah, 2010: 82; M alhotra \& Sharma., 2016: 134). 
Consequentially, examining the volatility spillover between the markets is important in terms of financial stability perspective and the links between the markets may have an impact on the success of the policies implemented in the financial markets. In addition, investigation of the volatility spillover between financial markets is important as it is a source of information where volatility generates new expectations for risks and returns.

\subsection{Literature Review}

The initial studies on volatility spillover between spot and futures markets focused on markets in the USA. Thereafter, the volatility spillover effect was investigated in several developed and emerging country markets. It could be suggested that the findings of the studies on volatility spillover between futures and spot markets demonstrated a highly heterogeneous structure in both developed and emerging country markets.

Koutmos and Tucker (1996) investigated the volatility correlation between S\&P 500 index spot and futures market returns with the end-of-day price data for the A pril 1, 1984-December 12, 1993 period and two-variable error-corrected E-GARCH model. The findings revealed that daily volatility was predictable in both markets based on previous market price changes. Furthermore, the spot market volatility was an asymmetric function of the historical price variations. Also, the same was observed in the futures market. It was observed that price changes in the futures market affected spot market volatility asymmetrically.

Chatrath, Christie-David and Dhanda (2002) analyzed the volatility spillover relationship between S\&P 500 index futures and spot markets using intra-daily 15-minute frequency data for the period between Jan/1993 and Dec/1996 with the two-variable GARCH model. The findings showed that there was a two-way volatility spillover between markets, but also volatility transmission from futures market to spot market was stronger. Thus, the role of the futures market was more significant in information transfer. It was also determined in the study that the reaction of the futures market to negative shocks was stronger when compared to the reaction to positive shocks.

L afuente-L uengo (2009) investigated the volatility spillover between S\&P 500 index spot and futures markets using intra-daily 15-minute frequency data for the January 17, 2000 N ovember 26, 2002 period. Empirical findings revealed a one-way causality between market volatilities, and the spillover effect was from the futures market to the spot market.

Bhar (2001) investigated the volatility spillover between AOI index futures returns and underlying spot index revenues, and whether market volatility exhibited an asymmetrical behavior in Australian markets using the end-of-day price data for J anuary 1989-December 1998 period with the two-variable EGARCH model. The findings demonstrated that the parameters that measured the effect of short-term deviations on conditional variance were positive in both markets; however, these were statistically significant only for the spot market. It was also found that volatility was asymmetric for the futures market returns. The findings on the permanence of volatility indicated that volatility shocks had a strong permanence trend and were higher in futures returns. Due to the cross-market impact of historical price changes, it was observed that declines in the futures market led to higher reactions to volatility in the spot market when compared to market gains. 
Lin et. al. (2002) studied the volatility spillover between TAIEX index futures and spot markets with the VECM and EGARCH models using the intra-daily five-minute frequency data for the January 5, 1999-M arch 31, 2000 period. The EGARCH model results revealed that the reaction of both markets was asymmetric to the news and there was a two-way volatility spillover between the markets. In other words, the penetration of the negative information to the market led to higher volatility when compared to positive information, and this was observed not only in the relevant market but also in the other market due to the spillover effect.

Wang and Chen (2007) examined the volatility spillover relationship between the TAIEX index spot and futures markets using multivariate GARCH-M MSKST model, using intradaily five-minute frequency data for the period between J uly 1-December 31, 2003. A nalysis findings revealed that the futures market shocks increased the spot market volatility, similarly, the spot market price changes were effective on futures market volatility. The two-way volatility spillover in question refers to the existence of a mutual flow of information between the spot and the futures markets. However, it was stated that the futures market was more efficient in terms of knowledge.

Patra and M ohapatra (2011) investigated the volatility spillover between CNX NIFTY index spot and futures returns with the intra-daily one-minute frequency data for January 1December 31, 2010 period using the GARCH model. In the study, it was determined that there was a two-way volatility spillover between the markets. However, it was also revealed that the intraday volatility in spot market returns had a stronger leading effect in predicting the movements in futures market intraday volatility.

Zhou and Wu (2016) analyzed the volatility spillover between CSI 300 index futures and spot markets using the intra-daily five-minute frequency data for J anuary 4 - September 31, 2013 period with four multivariate MGARCH models (DCC, CCC, Diagonal and BEKK $M G A R C H$ ). The analysis findings demonstrated that different models exhibited different outcomes. There were no volatility spillovers between markets based on the Diagonal model, while BEKK, CCC and DCC models revealed significant volatility spillover evidence between the markets. In the study, it was reported that the most suitable model for the dataset was the DCC-MGARCH. Based on the model, there was a two-way volatility spillover between the markets. Furthermore, it was determined that volatility spillover impact was negative from the spot to the futures market. In other words, the spot market volatility tended to reduce the conditional futures market volatility. However, the reverse volatility spillover tended to increase the conditional spot market volatility.

Tokat and Tokat (2010) studied the volatility spillover relationship between ISE 30 index futures and spot markets using end-of-day pricing data for the period of February 2005-J une 2009 using two-variable GARCH-BEKK model. The findings obtained indicated that the volatility transmission channel worked more efficiently from the spot market to the futures market. Accordingly, ISE 30 index futures market volatility was directly and indirectly influenced by historical volatility of the spot market. On the other hand, the spot market volatility, was indirectly influenced by the volatility of futures market in addition to its own shocks and historical market volatility. In addition, it was observed that there was a two-way information flow between these markets, and this situation showed an asymmetric behavior. 
Özdemir (2011) investigated the causality between ISE 30 index futures and spot markets using the end-of-day price data for the M ay 2, 2005-J uly 30, 2010 period with the Granger causality test. The study findings revealed a two-way causality between market volatilities. Furthermore, in the EGARCH analysis, it was determined that the impact of the negative news flow was higher on the spot market volatility when compared to the positive news flow. Okur and Çevik (2013) studied volatility spillover between ISE 30 index futures and spot markets using the intra-daily five-minute frequency data for the $M$ ay $1,2006-M$ ay 31, 2010 period with the causality test developed by Hong (2001) and Hafner and Herwart (2006) and the GARCH model. The Hong causality test revealed that there was causality from the spot market towards the futures market when the effect of structural breakages is ignored, and the spot market affected the futures market in the 15-minute frequency. The Hafner and Herwatz test results confirmed the above-mentioned correlation. However, in the GARCH model where structural breakages were taken into account, a two-way volatility spillover between the markets was determined. Despite the contradicting findings, the authors suggested that the spot market played a paramount role in the processing and transfer of knowledge.

Gök and Kalaycı (2014) studied the volatility spillover between ISE 30 index futures and spot markets using the intra-daily one-minute frequency data for the January 2, 2010 - M ay 18, 2012 period with the VECM-GARCH $(1,1)$-BEKK model. The study findings revealed a twoway transfer between the futures and spot market volatilities. Furthermore, it was observed that the spot market volatility was more persistent when compared to that of the futures market. However, based on the cross-market shocks and variance spillover, it was determined that the lagged market volatility was more effective on market volatility when compared to the cross-market volatility spillover. Also, it was determined that the impact of the futures market delayed shocks was higher on the futures market, in contrast, the spot market was more open to the effect of cross-market shock transfers.

\section{METHODOLOGY}

\subsection{The Data Set}

The study dataset included the BIST 30 (X U 030) index end-of-day closing prices and futures contracts based on the same index ( $\left.F \_X \cup 030\right)$ for the February 2, 2006 - A pril 30, 2020 period. The data were obtained from the Borsa Istanbul Historical and Reference Data Platform.

In the study, to avoid the impact of weak transactions in the futures market, the most concurrently traded futures contracts were analyzed on any given day. The data for the futures contract with the highest trading volume and closest contracts to this volume were determined in the analysis since the closest futures contracts were generally the most active contracts and included more information when compared to the prices of the further futures contracts. Furthermore, to avoid the expiration effect, when the trade volume of the closest futures contract at the closest time to the date of maturity was lower than the trade volume of the second closest futures contract, the second closest futures contract data were employed (www.borsaistanbul.com). 


\subsection{Research Methodology}

One of the most important constraints in symmetric ARCH and GARCH volatility models is the assumption that positive and negative shocks would have the same effect on variance. In these models, only the magnitude of the shock is important, and its sign is ignored. However, the majority of the previous studies revealed that negative shocks that represented bad news in financial markets had a greater impact on volatility when compared to positive shocks that represented good news (K outmos ve Tucker, 1996; Tse, 1999; Bhar, 2001; Lin et al., 2002; Bose, 2007; Özdemir, 2011). Thus, asymmetric conditional heteroscedasticity models that addressed different effects of the negative and positive shocks, namely, the asymmetric effects are required (Özden, 2008: 344).

One of the models that analyze the impact of asymmetric effects on volatility is the GJR GARCH model (Glosten et.al.,1993). The GJR-GARCH model, where the standard GARCH structure is preserved, is an extended GARCH model with the addition of a dummy variable to measure the impact of asymmetry. The model assumes that the impact of negative news flow (negative shocks, $u_{t-1}<0$ ) on conditional variance would be higher than the effects of positive news flow (positive shocks, $u_{t-1}>0$ ) on conditional variance, and this effect is measured by the $\mathrm{D}_{\mathrm{t}-\mathrm{i}}$ dummy variable added to the standard GARCH model. A significant difference in the approach is the inclusion of the $D_{t-i}$ dummy variable in the model with a value of 1 when $u_{t-1}$ is negative; otherwise, it will be 0 when $u_{t-1}$ is positive. Thus, the GJ $R$ GARCH model could determine the impact of good and bad news on conditional variance. The GJR-GARCH $(p, q)$ model is presented in Equation (1). In the equation, if $\gamma_{i} \neq 0$, then the effect of the next news would be different. Furthermore, when the effect size of the positive news flow is $\alpha_{i}$, then the effect size of a negative news flow will be $\alpha_{i}+\gamma_{i}$. When $\gamma_{i}>0$, the impact of the negative news on volatility will be greater than the impact of the positive news. In other words, a negative shock will cause more volatility than a positive shock. On the other hand, when $\gamma_{i}=0$, then the effect of the next news on volatility will not be asymmetrical, and the GRJ-GARCH model will be equal to the GARCH model (Dutta, 2014; Enders, 2015).

$$
\begin{array}{r}
h_{t}^{2}=\omega+\sum_{j=1}^{p} \beta_{j} h_{t-j}^{2}+\sum_{i=1}^{q} \alpha_{i} u_{t-i}^{2} \\
+\sum_{i=1}^{q} \gamma_{i} \mathrm{D}_{t-i} u_{t-i}^{2}
\end{array}
$$

Correlations between financial asset returns, risks, and volatilities are the fundamental factors in the determination of optimal investment strategies, especially those aim to protect the investors against risks (Changa, M cA leer \& Tansuchat, 2013: 117). Thus, univariate volatility models are inadequate in the analysis of time-varying correlations between the assets, and univariate volatility models led to the development of multivariate $\mathrm{GARCH}$ models that were required for in-depth financial analysis (Hinojales and Park, 2011:190). One of these methods was the DCC (Dynamic Conditional Correlation) GARCH model, which was an extended version of the CCC (Constant Conditional Correlation) GARCH model, developed by Bollerslev (1990), and then improved by Engle (2002). 
The DCC GARCH model allows the determination of time-varying dynamic conditional correlation coefficients between two variables and provides more detailed data when compared to unconditional correlation analysis in time-varying co-movements. The estimation is conducted in two stages in the model. In the first stage, the volatility of each variable is predicted with univariate GARCH models. In the second stage, the DCC model conditional correlation parameters are determined with the standardized residuals obtained in the first stage (K otkatvuori-Ö rnberg, 2016: 62).

Engle discussed this procedure for a return $(r)$ vector with $k$ observation that should be multivariate and with normal distribution as follows (Engle, 2002: 342):

$\mathrm{r}_{\mathrm{t}} \mid \Phi_{\mathrm{t}-1} \sim \mathrm{N}\left(0, \mathrm{H}_{\mathrm{t}}\right)$

Here $\mathrm{H}_{\mathrm{t}}$ is the conditional variance-covariance matrix and calculated with Equation (3). This matrix is obtained with the Dt matrix, a $\mathrm{k} \times \mathrm{k}$ dimensional diagonal matrix that includes timevarying standard deviations, and the $\mathrm{R}_{\mathrm{t}}$, also a $\mathrm{k} \times \mathrm{k}$ dimensional time-varying correlation matrix (Bodnar and Hautsch, 2016: 44):

$H_{t} \equiv D_{t} R_{t} D_{t}$

Here, $D_{t}$ matrix is derived from the univariate $\operatorname{GARCH}(p, q)$ structure presented in Equation (4) (Hemche, J awadi, M aliki, Cheffou, 2016: 294).

$h_{t}=\omega+\sum_{j=1}^{p} \beta_{j} \mathrm{~h}_{t-j}+\sum_{i=1}^{q} \alpha_{i} u_{t-i}^{2}$

Each return vector is proportioned to its conditional standard deviation $\left(\sqrt{h_{i t}}\right)$, to obtain the standardized return vectors $\left(u_{t}=D_{t}^{-1} r_{t}\right)$. Thus, the dynamic correlation specification in Equations (5) and (6) is achieved, where $\widetilde{Q}_{t}$ is the unconditional covariance matrix of error terms. Furthermore, for $\alpha^{*} \mathrm{~m}$ and $\beta^{*}$ n parameters, $\sum_{m} \alpha_{m}^{*}+\sum_{n} \beta_{n}^{*}<1$ limitation is valid. This specification, determined by Engle (2002), is referred to as the DCC $(m, n)$ model. Here, volatility component $D_{t}$ and correlation component $R_{t}$ are obtained with the respective maximization of the likelihood functions; hence the two-step estimation procedure (Engle, 2002: 342).

$$
\begin{aligned}
& \begin{aligned}
Q_{t}=\left(1-\sum_{m} \alpha_{m}^{*}-\sum_{n} \beta_{n}^{*}\right) \tilde{Q}+\sum_{m} \alpha_{m}^{*}\left(\mathrm{u}_{t-m} u_{t-m}^{\prime}\right) \\
+\sum_{n} \beta_{n}^{*} \mathrm{Q}_{t-n}
\end{aligned} \\
& \mathrm{R}_{\mathrm{t}}=\operatorname{diag}(\mathrm{Q})^{-1} \mathrm{Q}_{1} \operatorname{diag}(\mathrm{Q})^{-1}
\end{aligned}
$$




\section{RESULTS}

In the present, various effects of negative and positive shocks on market volatility, spillover effects between market return volatility, and time-varying dynamic conditional correlations were analyzed.

For this purpose, the series unit root test was conducted with the ADF unit root test. It was concluded that the trend and intercept model for both series was the correct model for the ADF unit root test, and the test results are presented in Table 1. A kaike Information Criterion (AIC) was employed to determine the optimal lag.

Table 1: ADF Unit Root Test Results

\begin{tabular}{|l|l|l|l|l|l|l|}
\hline \multicolumn{2}{|c|}{} & \multicolumn{2}{|l|}{ t-İstatistiği } & Prob. \\
\cline { 3 - 7 } \multicolumn{2}{|c|}{} & LogSpot & LogV adeli & LogSpot & LogV adeli \\
\hline ADF Test İstatistiği & & -3.246306 & -3.353273 & 0.0757 & 0.0580 \\
\hline \multirow{3}{*}{ Kritik değerler } & $1 \%$ & -3.96142 & & & & \\
\cline { 2 - 3 } & $5 \%$ & -3.41146 & & & & \\
\cline { 2 - 3 } & $10 \%$ & -3.12759 & & & & \\
\end{tabular}

The review of the ADF unit root test results demonstrated that the test statistics for the level values in both series were lower when compared to MacKinnon's (1996) critical values. Thus, the null hypotheses that the series included unit-roots or were not stationary at that level could not be rejected. The test statistics after the first differences of the series were taken were rejected since they were smaller than the critical values, and the alternative hypothesis that the series were stationary was accepted at $10 \%$ statistical significance.

Return series included in Equations (7) and (8) were obtained with the logarithmic first differences of the end-of-day price series for the variables. The return series are presented in Graphs 1 and 2, where the $X$-axis is the time, and the $Y$-axis reflects the returns.

$\Delta \mathrm{S}_{t}=\mathrm{S}_{t}-\mathrm{S}_{t-1}=\ln \left(\mathrm{P}_{\mathrm{s}, \mathrm{t}}\right)-\ln \left(\mathrm{P}_{\mathrm{s}, \mathrm{t}-1}\right)=\ln \left(\mathrm{P}_{\mathrm{s}, \mathrm{t}} / \mathrm{P}_{\mathrm{s}, \mathrm{t}-1}\right)=\mathrm{Rs,t}$

$\Delta \mathrm{V}_{t}=\mathrm{S}_{t}-\mathrm{V}_{t-1}=\ln \left(\mathrm{P}_{\mathrm{v}, \mathrm{t}}\right)-\ln \left(\mathrm{P}_{\mathrm{v}, \mathrm{t}-1}\right)=\ln \left(\mathrm{P}_{\mathrm{v}, \mathrm{t}} / \mathrm{P}_{\mathrm{v}, \mathrm{t}-1}\right)=\mathrm{R}_{\mathrm{v}, \mathrm{t}}$

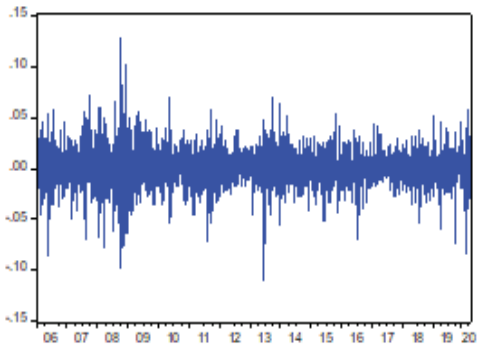

Graph 1: Spot M arket Return Series

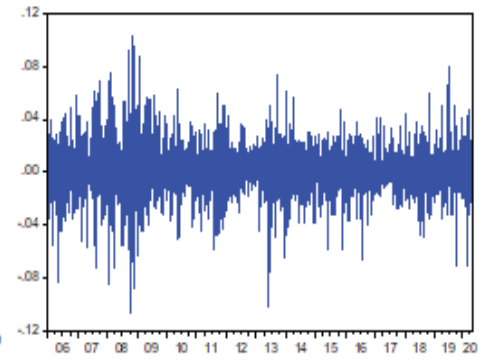

Graph 2: Futures M arket Return Series 
Before the two-vector autoregression (VAR) model where the spot and futures market returns were the dependent variables was estimated, results presented in Table 2 were determined with the lag length selection criteria based on VAR analysis to determine the adequate lag for the V A R models. Thus, it was suggested that the second lag length indicated by the Schwartz information criterion and supported by the Hannan-Quin information criterion was the suitable lag for the model.

Table 2: Lag Length Selection Criteria in VAR

\begin{tabular}{ccccccc}
\hline Lag & LogL & LR & FPE & AIC & SC & HQ \\
\hline 0 & 16807.98 & NA & $1.32 \mathrm{e}-08$ & 12.46734 & -12.46297 & -12.46576 \\
1 & 17086.32 & 556.0695 & $1.08 \mathrm{e}-08$ & 12.67086 & -12.65773 & -12.66611 \\
2 & 17157.03 & 141.1591 & $1.02 \mathrm{e}-08$ & 12.72035 & $-\mathbf{1 2 . 6 9 8 4 7 *}$ & $-\mathbf{1 2 . 7 3 1 3 1 *}$ \\
3 & 17171.69 & 29.22846 & $1.02 \mathrm{e}-08$ & 12.72825 & -12.69762 & -12.72717 \\
4 & 17183.11 & 22.77190 & $1.01 \mathrm{e}-08$ & 12.73376 & -12.69437 & -12.71952 \\
5 & 17188.87 & 11.48033 & $1.01 \mathrm{e}-08$ & 12.73507 & -12.68693 & -12.71766 \\
\hline
\end{tabular}

Estimations obtained with the VAR model are presented in Table 3. Thus, it was observed that the coefficients for all lagged values were statistically significant in both models. This indicated that both market returns were affected both by their own and other market lagged values (Zhou \& Wu, 2016: 1012). Consequently, it could be suggested that there was a causality between the futures and spot market returns in BIST 30 index.

Table 3: VAR Model Results

\begin{tabular}{ccc}
\hline & $\begin{array}{c}\text { Dependent V ariable: Spot } \\
\text { Market Return }\end{array}$ & $\begin{array}{c}\text { Dependent V ariable: } \\
\text { Futures M arket Return }\end{array}$ \\
\hline$\Delta G_{S}(-1)$ & -0.19105 & $\Delta G_{V}$ \\
& $(0.05318)$ & 0.28661 \\
& {$[-3.59239]$} & $(0.05475)$ \\
$\Delta G_{S}(-2)$ & -0.06231 & {$[5.23470]$} \\
& $(0.03014)$ & 0.12956 \\
$\Delta G_{V}(-1)$ & {$[-2.06735]$} & $(0.05454)$ \\
& 0.20741 & {$[2.37536]$} \\
$\Delta G_{V}(-2)$ & $(0.05164)$ & -0.27275 \\
& {$[4.01654]$} & $(0.05317)$ \\
& & {$[-5.13032]$} \\
& 0.09551 & -0.10942 \\
& $(0.04265)$ & $(0.05325)$ \\
& {$[2.23944]$} & {$[-2.05495]$} \\
\hline
\end{tabular}

(V alues in square brackets are t statistics.)

To determine the direction of causality between the market returns, Granger Causality Test was applied on the VAR model to obtain the short-term correlation between the price series, and the findings are presented in Table 4. 
Table 4: VAR Granger Causality / B lock-Exogeneity Test Results

\section{$\mathrm{H}_{0}$ : Futures market return changes does not Granger cause spot}

Panel A market return changes

Chi-Square : 16.136 Prob : [0.0003]

$\mathrm{H}_{0}$ : Spot market return changes does not Granger cause futures

Panel $\mathrm{B}$ market return changes

Chi-Square: : 25.572 Prob : [0.0000]

Panel A in Table 4 demonstrated that the null hypothesis that the variations in BIST 30 index futures returns did not lead to the price variations in the BIST 30 index was rejected at $1 \%$ significance level. Furthermore, in Panel $B$, it was observed that the null hypothesis that the variations in BIST 30 index returns did not lead to price variations in BIST 30 futures contracts was rejected at $1 \%$ statistical significance. Thus, based on the Granger causality test results, a two-way causality was determined between the variations in BIST 30 index and BIST 30 index futures returns. The absence of the one-way causality between spot and futures market returns demonstrated that one of these markets did not lead to the other one, i.e., there was no lead-lag correlation between the markets.

In the study, before the volatility was modeled, whether BIST 30 index spot and futures market return series error terms included sequential dependence and autoregressive conditional heteroscedasticity effect (ARCH effect). Ljung-Box Q statistics and $\mathrm{Q}^{2}$ statistics were applied for 1, 4, 8, and 12 lags, and their p-values are presented in Table 5. Q statistics were employed to determine whether there was an autocorrelation in the error terms. The findings demonstrated that the null hypothesis that there was no autocorrelation in all lagged values for both series was not rejected $(p>0.05) . Q^{2}$ statistics for the squared errors employed to determine the existence of the A RCH effect demonstrated that the null hypothesis that error terms did not have an $\mathrm{ARCH}$ effect in all lagged values in both series was rejected at $1 \%$ significance level. These findings demonstrated that (G)A RCH-type models should be used in volatility models.

Table 5: Test Results for Error Terms

\begin{tabular}{lllll}
\hline Error Terms & $\mathrm{Q}_{(1)}$ & $\mathrm{Q}_{(4)}$ & $\mathrm{Q}_{(8)}$ & $\mathrm{Q}_{(12)}$ \\
\hline \multirow{2}{*}{ Spot M arket } & 0.0003 & 0.2467 & 11.602 & 19.835 \\
& $(0.985)$ & $(0.993)$ & $(0.170)$ & $(0.070)$ \\
Futures M arket & 0.008 & 0.8391 & 7.7685 & 10.585 \\
& $(0.929)$ & $(0.933)$ & $(0.456)$ & $(0.565)$ \\
\hline Error Terms & $\mathrm{Q}^{2}(1)$ & $\mathrm{Q}^{2}(4)$ & $\mathrm{Q}^{2}(8)$ & $\mathrm{Q}^{2}(12)$ \\
\hline \multirow{2}{*}{ Spot M arket } & 28.260 & 271.34 & 489.27 & 635.46 \\
& $(0.000)$ & $(0.000)$ & $(0.000)$ & $(0.000)$ \\
Futures M arket & 36.926 & 314.24 & 550.13 & 768.99 \\
& $(0.000)$ & $(0.000)$ & $(0.000)$ & $(0.000)$ \\
\hline
\end{tabular}

(V alues in parentheses are p-values.) 
In the study, the GJR-GARCH model was employed to analyze the asymmetric effects on the volatility of the markets, and the DCC-GARCH model was employed to analyze the volatility spillover between the market volatilities. However, before the model was estimated, it was necessary to determine whether the average model residuals exhibited normal distribution. Thus, quantile-quantile (q-q) residual plots were drawn as presented in Graph 3, and it was determined that both distributions resembled a low degree of freedom in student's $t$ distribution, and did not exhibit a normal distribution. Thus, the GARCH model was estimated based on the student's t distribution assumption.

Graph 3: Quantile-Quantile (q-q) Plots of VAR Residuals

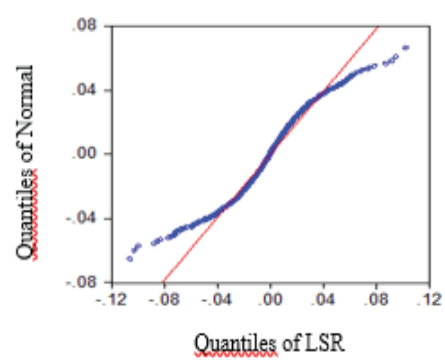

Spot Market

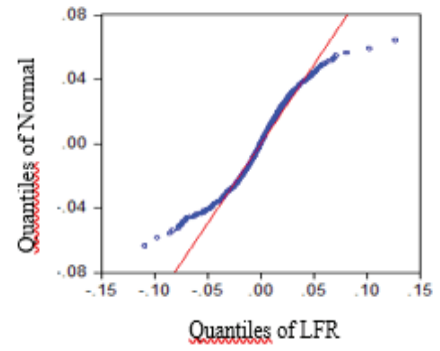

Futures Market

The results of GJR-GARCH and DCC-GARCH models employed to estimate the volatility of BIST 30 index spot and futures markets are presented in Table 6.

In the GJR-GARCH model, it was assumed that a negative news flow (negative shocks, $u_{t}$ $\left.{ }_{1}<0\right)$ would have a higher impact on volatility when compared to a positive news flow (positive shocks, ut-1>0). Thus, if $\gamma_{i}>0$, then the impact of negative news on volatility would be greater than the impact of positive news. In other words, an asymmetric or leverage effect would be observed, where the effect size of the positive news flow is $\alpha_{i i}$, and the effect size of the negative news flow is $\alpha_{i i}+\gamma_{i}$.

The analysis of the findings presented in Table 6 demonstrated that the $\gamma_{i}$ coefficient was greater than 0 in both models. This revealed a leverage effect in both spot and futures markets. In other words, both markets reacted strongly against the negative market shocks when compared to the positive market shocks. The impact of the positive news flow on the spot and futures market volatility was approximately $\% 3\left(\alpha_{11}=0.03 ; \alpha_{22}=0.03\right)$, while the impact of the negative news flow on the spot market volatility was approximately $\alpha_{11}+\gamma_{1}=0.13$, it is $\alpha_{22}$ $+\gamma_{2}=0.09$. This finding demonstrated that the impact of negative shocks was higher on the spot market when compared to the futures market. 
Table 6: GJ R- GARCH and DCC-GARCH Model Estimation Results

\begin{tabular}{cllll}
\hline & Coefficient & Standard Error & t-statistic & $p$-value \\
\hline$C_{11}$ & 0.118380 & 0.0411 & 2.877 & 0.0040 \\
$C_{21}$ & 0.000312 & 0.00026034 & 1.200 & 0.2302 \\
$\alpha_{11}$ & 0.034991 & 0.012282 & 2.849 & 0.0044 \\
$\alpha_{12}$ & 0.118380 & 0.041141 & 2.877 & 0.0040 \\
$\alpha_{21}$ & 0.089841 & 0.041509 & 2.164 & 0.0305 \\
$\alpha_{22}$ & 0.036049 & 0.010865 & 3.318 & 0.0009 \\
$\beta_{11}$ & 0.873596 & 0.030055 & 29.07 & 0.0000 \\
$\beta_{12}$ & 0.904714 & 0.029109 & 31.08 & 0.0000 \\
$\beta_{21}$ & 0.968199 & 0.0083332 & 116.2 & 0.0000 \\
$\beta_{22}$ & 0.910502 & 0.25584 & 3.559 & 0.0006 \\
& & & & \\
& & & & \\
$\gamma_{1}$ & 0.878127 & 0.0022940 & 426.4 & 0.0000 \\
$\gamma_{2}$ & 0.101219 & 0.030429 & 3.326 & 0.0009 \\
\hline
\end{tabular}

In Table $6, \alpha_{11}$ and $\alpha_{22}$ parameters depict the permanence of short-term volatilities in the spot and futures markets (ARCH effect), and $\beta_{11}$ and $\beta_{22}$ parameters reflect the permanence of long-term volatilities in the spot and futures markets (GARCH effect). $\alpha_{12}$ (in the short-term) and $\beta_{12}$ (in the long-term) refer to the impact of volatility spillover from the spot market to the futures market, while $\alpha_{21}$ (in the short-term), $\beta_{21}$ (in the long-term) refer to the effect of volatility spillover from the futures market to the spot market. Furthermore, $\rho$ is the constant conditional correlation coefficient between the variables.

The analysis of the findings presented in Table 6 demonstrated that all parameters, except the $\mathrm{C}_{21}$ constant, were statistically significant. The short-term spot market volatility permanence was about $\% 3$ in both markets $\left(\alpha_{11}=0.03, \alpha_{22}=0.06\right)$. The long-term volatility was approximately $\beta_{11}=0.87$ and $\beta_{22}=0.91$ in the spot and the futures markets, respectively. Thus, it was observed that the long-term volatility permanence in both markets was close to 1 , and played a more significant role in estimating the conditional volatility in the next period.

The fact that all volatility spillover parameters were significant demonstrated that there was a two-way volatility spillover between the markets. This was consistent with the findings obtained in the VAR-Granger causality analysis that investigated the correlation between the market returns. The effect of volatility spillover from the spot market to the futures market was approximately $\alpha_{12}=0.11$ and $\beta_{12}=0.96$ in the short and long term, respectively. The effect of short and long-term volatility spillovers from the futures market to the spot market was approximately $\alpha_{21}=0.08$ and $\beta_{21}=0.96$, respectively. Thus, the volatility spillover effect from one market to the other increased the conditional volatility of the other market and was valid for both markets. The effect of volatility spillover from the spot market to the futures market was almost similar $\left(\alpha_{12}=0.11\right)$, and the volatility spillover effect was in the opposite direction $\left(\alpha_{21}=0.08\right)$. It could be suggested that the long-term volatility spillovers were similar $\left(\beta_{12}=0\right.$. 0.90 and $\left.\beta_{21}=0.96\right)$ in both markets. Thus, it could be argued that both markets played almost similar roles in the transfer of volatility information. 
The analysis of time-varying dynamic conditional correlations between BIST 30 index spot and futures market daily return volatilities would provide detailed data on the correlation between the variables. In the study, time-varying dynamic conditional correlation coefficients between these variables were calculated with the DCC-GARCH method.

Graph 4: Dynamic Conditional Correlation Graph Between BIST 30 Spot and Futures $M$ arket $\mathrm{V}$ olatilities

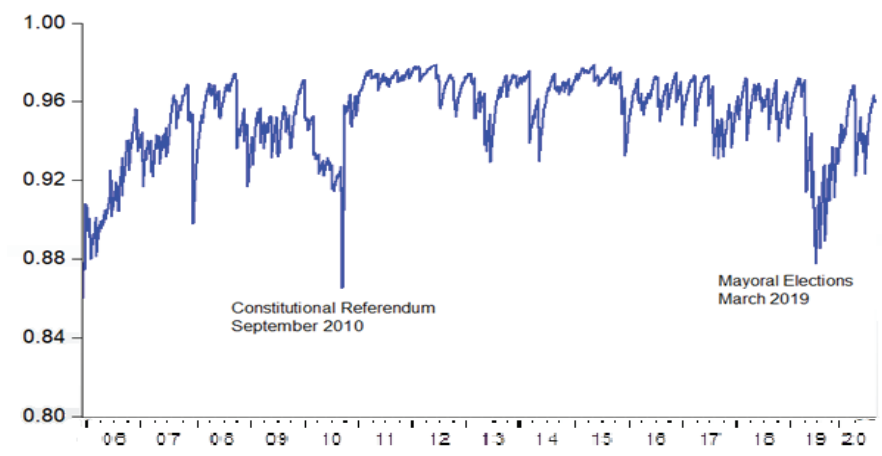

The dynamic conditional correlation between the daily return volatilities in BIST 30 index spot and futures markets is presented for the between February 2, 2006-A pril 30, 2020 period in Graph 4. The review of the graph would demonstrate that the correlation between the daily return volatilities of the variables was quite high. The constant correlation coefficient between the series was about 0.88 ( $\rho=0.878127)$ as presented in Table 5 . The overall mean dynamic conditional correlation coefficient was about 0.95 . It was observed that the lowest dynamic conditional correlation coefficient was 0.86 and the highest coefficient was 0.98 . Furthermore, it was observed that the dynamic conditional correlation coefficient between the market return volatilities during August and September of 2010 dropped to the levels of the dynamic conditional correlation coefficients recorded during the initial phase of the futures market. Also, the dynamic conditional correlation coefficient between the markets decreased sharply in December 2018 and remained below average until J une 2019. These declines indicated that the correlation between the BIST 30 spot and futures markets weakened during the 2008 global financial crisis and the crisis in the Turkish economy after the third quarter of 2018. However, the fact that this coefficient was positive and close to ' 1 ' during the period of the analysis indicated a high dynamic conditional correlation in the same direction. In other words, a movement observed in the series was passed to the other series. This finding was consistent with the findings of the Granger causality test conducted with the V A R model.

\section{DISCUSSION}

In the present study, the volatility spillover between Turkish futures and spot markets was analyzed using the BIST 30 index end-of-day price data for the February 2, 2006 - A pril 30, 2020 period. The present study contributed to the literature and it was different from previous studies conducted in Turkey since various asymmetric effects of negative and positive shocks 
on market volatility were analyzed with the GJR-GARCH method, as well as the spillover and time-varying dynamic conditional correlation between the market return volatilities with the DCC-GARCH method.

In the study, return series were obtained primarily with the logarithmic first differences of the end-of-day pricing series for the variables. Thereafter, the conducted VAR analysis revealed that both market returns were affected by both their lag values and the lag values of the other market. Subsequently, the causality between the market returns was tested with the Granger causality test in the VAR model. The analysis findings indicated that there was a two-way causality between the returns of the markets.

The GJR-GARCH model revealed that both markets reacted strongly to the negative shocks in the market when compared to the positive shocks. This finding demonstrated a leverage effect in both spot and futures markets. Black (1976) and Christie (1982), who first suggested the leverage effect, determined that negative returns led to higher volatility when compared to positive returns. Thus, the authors suggested that a decline in the value of a financial asset led to a riskier entity, which in turn led to a higher increase in the volatility of the asset, which was christened as the leverage effect by the authors. The present study findings revealed leverage effects in both spot and futures markets. This could be associated with the fact that investors were more susceptible to negative news flows in both markets. Furthermore, the degree of asymmetry in the spot market was higher than in the futures market. The fact that the investor and the transaction volume in the spot market were relatively higher when compared to the futures market could be the reason for the above-mentioned finding.

It was observed that the number of studies on the impact of negative and positive shocks on market volatility in Turkey and other emerging markets was very limited. The present study findings were consistent with the findings reported by Özdemir (2011) on Turkish markets, by Lin et al. (2002) on Taiwanese markets, and by Bose (2007) on Indian markets.

It was determined in the present study that the long-term persistence of volatility in both markets was very close to 1 , and it played a more significant role in the estimation of the conditional volatility of the next period when compared to the short-term volatility persistence. Thus, it could be suggested that daily volatility was predictable in both markets based on previous market price variations. Furthermore, the DCC-GARCH model demonstrated that there was a two-way volatility spillover between the markets, and the impact of the existing volatility spillovers from one market to the other increased the conditional volatility of the other market. In other words, there was a strong dependence between the markets in return volatility, and the volatility in spot and futures market returns could explain the other, revealing a statistically significant spillover effect. Furthermore, the findings indicated that both markets played an approximately equal role in the transfer of volatility information.

The overall analysis of the GJR-GARCH and DCC-GARCH models demonstrated that a news flow to the market was effective on both market volatility and volatility of the other market. Thus, past market return shocks affected both the current market volatility and the current volatility of the other market. Thus, the absence of a perfect simultaneous correlation 
between the variations in two markets was not consistent with the effective market hypothesis.

The volatility spillover findings were consistent with the results reported by Özdemir (2011), and Gök and Kalayc1 (2014) where the authors investigated the spillover between ISE 30 index futures and spot market volatilities. Furthermore, in studies on emerging markets, the studies conducted by Sakthivel and Kamaiah (2010), Patra and M ohapatra (2011), Pati and Rajib (2011), and Paul and K imata (2016) on Indian markets, Y ang et al. (2012), Zhou et al. (2014) and Zhou and Wu (2016) on Chinese markets, and K ang et al. (2013) on South Korea markets reported two-way spillover between the volatilities of the scrutinized markets, similar to the findings reported in the present study. However, the present study finding that the futures market volatility persistence was slightly higher than that of the spot market was in contrast with the reports by Gök and Kalaycı (2014) for the ISE 30 index.

Finally, in the present study, the time-varying dynamic conditional correlation between BIST 30 index spot and futures market volatilities was analyzed with the DCC-GARCH method. Thus, during the period of analysis, it was observed that the dynamic conditional correlation coefficient between the variables was continuously positive and varied between 0.86 and 0.98 . This suggested that there was a strong dependence on market return volatilities, and volatility information produced by the spot or futures markets were transferred to the other market. Thus, it could be suggested that the profit potential of the arbitrage opportunities across the two markets was quite low.

\section{CONCLUSION}

The overall analysis of the present study findings demonstrated that there was a mutual causality between volatility in BIST 30 index spot and futures markets, and there were no lead-lag correlations between the markets. Thus, the study findings supported the hypothesis that new information spilled over in both markets, and both markets played a role in volatility spillover. This finding contradicted the hypothesis that futures markets, characterized by lower transaction costs and higher leverage, played a key role in information transfer. Furthermore, according to the efficient market hypothesis, the variations in spot and futures market prices would occur at the same time. Therefore, the current change in futures price would not be associated with the previous change in spot price and the current change in spot price would not be associated with the previous change in futures price. However, the more efficient market would process the information faster, and this market would lead the other. Thus, it could be argued that the information transfer function was an indicator of the relative effectiveness of the market where the relevant financial assets were traded. However, based on the present study findings, one could not conclude that one of the scrutinized markets was more effective than the other.

The transaction volume and the number of investors in the futures market were quite low when compared to the spot market in Turkey. The underlying factors could be summarized as follows: Derivatives market is quite new in Turkey, investors do not have adequate knowledge on the market, the risk management culture is not prevalent when compared to the developed markets, and economic and political instability prevails in the country. Thus, it 
could be suggested that the derivatives market is still in the development stage. These factors could have affected the present study finding that the futures market prices did not have a leading impact on the spot market prices.

The lack of full and considerable knowledge on futures markets in emerging countries and the difficulties in the comprehension of futures transactions lead to a failure in attracting investors and prevent investors from trading in the futures market. Thus, for the improvement of futures market returns, the regulatory authorities should conduct informative activities for individual and institutional investors on risk management and investments to raise interest in the futures market in developing countries. However, it was observed that transaction volume has increased gradually in emerging country futures markets. If this trend continues and the interest in the futures markets improves as investors become aware of risk management over time, the lead-lag correlation between the market prices could also change.

The present study findings could also ensure that investors, who closely monitor significant economic and political developments that could lead to shocks in spot and futures markets, could understand the volatility spillover; and thus, could determine the best investment strategies for risk protection or profits. The correlations between financial asset returns, risks, and volatilities are fundamental factors that could help determine optimal investment strategies, especially those that aim for risk protection. Thus, it could be suggested that the present study findings could guide the investors who trade in both markets.

The fact that the correlation between the spot and futures market volatility was discussed only based on the BIST 30 index daily data could be considered as the limitation of the current study. However, the study would still contribute to the literature due to the limited number of studies on the volatility between futures and spot markets in Turkey. Furthermore, as far as we know, the present study is the first where the dynamic conditional correlation between the scrutinized market volatilities was analyzed. Future studies could address the correlation between spot and futures markets based on other futures contracts in both local and international markets with intraday data, and investigate the impact of transaction volume on volatility spillover.

\section{BIST 30 VADELI İŞLEM ve SPOT PIYASALARI ARASINDA VOLATÍLITE YAYILIMI İLIŞKISII: DCC-GARCH ANALIZI}

\section{GíRIŞ}

Vadeli işlem piyasalarının temel fonksiyonu, gelecekteki muhtemel fiyat değişikliklerine karşı korunmayı amaçlayan kişi ve kurumlara, fiyat riskinden korunmaya yönelik birtakım finansal enstrümanlar sunmasıdır. Bir yatırımcının, varlığın fiyatında oluşabilecek risklerden kaçınmak amacıyla vadeli işlem piyasalarını kullanması, ancak ilgili varlık veya bu varlıkla yakından bağlantılı bir başka varlık üzerine düzenlenen türev sözleşmenin seçilmesiyle mümkün olabilmektedir. Türev sözleşmeler, spot piyasa enstrümanları olan emtia, hisse senedi, tahvil, endeks gibi varlıklar üzerine düzenlenmektedir. Bu nedenle, vadeli işlem piyasalarının spot piyasalar ile olan ilişkisi, finans alanında ele alınan temel konulardan biri haline gelmiştir. 
Vadeli işlem piyasaları ile spot piyasalar arasındaki söz konusu bu ilişkinin incelenen bir yönü de volatilite yayılımı kavramıla ifade edilmektedir.

Volatilite yayılımı, bir piyasadaki volatilite şoklarının bir sonraki işlem döneminde diğer piyasa volatilitesi üzerinde yayılım etkisi göstermesidir. Volatilite yayılımının temel özelliği, bilginin piyasalar arasında (kısa vadeli) getiri volatilitesinde ardışık değişikliklerle hızla iletilmesidir. Bu bağlamda, iki piyasa arasında volatilite yayılımının varlığı, bir piyasadaki getirilere ait volatilitenin diğer piyasa getirilerinin volatilitesi üzerinde önemli bir etkisinin olduğu anlamına gelmektedir.

\section{YÖNTEM}

Bu çalışmanın amacı, Türkiye'de vadeli işlem piyasası ile spot piyasa arasındaki volatilite yayılımı ilişkisini, BIST 30 endeksi bağlamında, gün sonu fiyat verilerini kullanarak araştırmaktır. $\mathrm{Bu}$ amaçla, öncelikle VAR modeline dayalı Granger nedensellik testi kullanılarak BIST 30 endeksi bağlamında, spot ve vadeli işlem piyasa getirileri arasındaki nedensellik iliş̧isi incelenmiştir. Ardından GJR-GARCH yöntemi ile negatif ve pozitif şokların volatilite üzerindeki farklı etkisi, başka bir deyişle kaldıraç etkisinin varlığı araştırılmıştır. Son olarak, DCC-GARCH yöntemi ile piyasa getiri volatiliteleri arasındaki yayılım ilişkisi ve zamana göre değişen dinamik koşullu korelasyon ilişkisi ele alınmıştır.

\section{BULGULAR}

Uygulanan Granger nedensellik test sonuçlarına göre, BIST 30 endeksi ile bu endekse dayalı vadeli işlem sözleşmeleri getiri değişimleri arasında iki yönlü bir nedensellik ilişkisinin varlığ 1 tespit edilmiştir. Yani, vadeli işlem sözleşmelerine ait getiri değişimleri, BIST 30 endeksindeki değişimleri etkilerken; BIST 30 endeksindeki değişimler de vadeli işlem sözleşmelerindeki getiri değişimlerini etkilemektedir. Spot ve vadeli işlem piyasa getirileri arasında tek yönlü bir nedensellik ilişkisinin bulunmaması, bu piyasalardan birinin diğerine öncülük etmediğini, başka bir deyişle piyasalar arasında bir liderlik-gecikme ilişkisinin olmadığını ortaya koymaktadır.

Çalışmada, spot ve vadeli işlem piyasa getiri volatilitelerinin modellenmesinde, asimetrik etkilerin volatilite üzerindeki etkisini inceleyen GJ R-GARCH modeline göre her iki piyasanın da pozitif şoklarla kıyaslandığında negatif şoklara daha fazla reaksiyon gösterdiği ortaya konmuştur. Bununla birlikte, negatif şokların etkisinin spot piyasada vadeli işlem piyasasına göre daha fazla olduğu tespit edilmiştir. Bu sonuç, her iki piyasa için de geçerli olacak şekilde, yatırımcıların piyasaya gelen negatif haberlere karşı daha duyarlı olmalarıyla ilişkilendirilebilir. Ayrıca, spot piyasaya ait asimetri derecesinin, vadeli işlem piyasasına kıyasla daha yüksek olduğu tespit edilmiştir. Spot piyasada yatırımcı sayısı ve işlem hacminin vadeli işlem piyasasına nispeten daha yüksek olmasının, böyle bir bulguya ulaşılmasında etkili olabileceği düşünülmektedir.

Uygulanan DCC-GARCH modeli ise, piyasalar arasında iki yönlü bir volatilite yayılımının varlığına işaret etmektedir. Başka bir deyişle, getiri volatiliteleri bağlamında, iki piyasa arasında güçlü bir bağımlılık ilişkisi söz konusudur ve spot ve vadeli işlem piyasa getirilerine 
ait volatiliteler, istatistiksel olarak anlamlı bir yayılım etkisi ortaya koyacak şekilde birbirlerini açıklayabilmektedir. Kısa ve uzun dönemde, spot piyasadan vadeli işlem piyasasına doğru volatilite yayılım etkisi sırasıyla yaklaşık olarak $\alpha 12=0.21$ ve $\beta 12=0.97$ 'dir. Vadeli işlem piyasasından spot piyasaya doğru kısa ve uzun dönem volatilite yayılım etkisi ise, sırasıyla yaklaşık olarak $\alpha 21=0.19$ ve $\beta 21=0.98$ 'dir. Dolayısıyla her iki piyasa için de geçerli olacak şekilde, bir piyasadan diğerine doğru gerçekleşen volatilite yayılım etkisi diğer piyasanın koşullu volatilitesini artırmaktadır. Kısa dönemde spot piyasadan vadeli işlem piyasasına doğru volatilite yayılım etkisi $(\alpha 12=0.21)$ ile tersi yöndeki $(\alpha 21=0.19)$ volatilite yayılım etkisi arasında çok az bir fark bulunmaktadır. Uzun dönem volatilite yayılım etkisinin ise, her iki piyasa için de yaklaş1k değerlere $\left(\beta_{12}=0.97\right.$ ve $\left.\beta_{21}=0.98\right)$ sahip olduğu görülmektedir. $\mathrm{Bu}$ bağlamda, volatilite bilgisinin iletiminde her iki piyasanın yaklaşık olarak eşit bir role sahip olduğunu söyleyebilmek mümkündür.

Dinamik koşullu korelasyon katsayısının incelenen dönem boyunca pozitif ve 1'e çok yakın değerler alması, değişkenler arasındaki dinamik koşullu korelasyon ilişkisinin oldukça yüksek ve aynı yönlü olduğuna, başka bir ifadeyle bir seride gözlemlenen bir hareketin diğerine geçtiğine işaret etmektedir.

\section{TARTIŞMA}

Çalışmadan elde edilen bulgular genel olarak değerlendirildiğinde, BIST 30 endeksi spot ve vadeli işlem piyasalarında meydana gelen volatilite değişimleri arasında iki yönlü bir nedensellik ilişkisinin olduğu ve piyasalar arasında bir liderlik-gecikme ilişkisinin bulunmadığı söylenebilir. Dolayısıyla çalışmanın bulguları, yeni bilginin her iki piyasada da yayıldığı hipotezini desteklemektedir. Elde edilen bu sonuç, daha düşük işlem maliyetleri ve daha yüksek kaldıraç etkisi ile karakterize olan vadeli işlem piyasalarının bilginin iletiminde baskın bir rol oynadığı hipotezi ile çelişmektedir. Ayrıca, etkin piyasa hipotezine göre, spot ve vadeli işlem fiyatlarındaki değişim aynı zamanda ortaya çıkacak ve bir piyasadaki fiyat değişiminin diğer piyasa fiyatındaki önceki değişim ile ilgisi olmayacaktır. Bununla birlikte, daha etkin olan piyasanın bilgiyi işleme süreci daha hılı olacak, dolayısıyla böyle bir piyasa diğer piyasaya öncülük edecektir. Bu açıdan, bilginin iletimi fonksiyonunun, ilgili finansal varlıkların işlem gördüğü piyasaların göreceli etkinliğinin bir belirtisi olduğunu söyleyebilmek mümkündür. Ancak, çalışmanın bulguları ele alınan piyasalardan birinin diğerine kıyasla daha etkin olduğuna yönelik bir sonuç ortaya koymamıştır.

\section{SONUÇ}

Gelişmekte olan ülkelerde türev piyasalar hakkında tam ve anlaşılır bilgi düzeyine sahip olunmaması ve vadeli işlemlerin anlaşılmasındaki güçlükler, vadeli işlem piyasalarının yatırımcıların ilgisini yeterince çekememesine sebep olmakta ve yatırımcılar tarafından etkin bir şekilde kullanılmasında engel teşkil etmektedir.

Türkiye'de yatırımcıların vadeli işlem piyasasına dair yeterince bilgi sahibi olmamaları, gelişmiş piyasalarla karşılaştırıldığında risk yönetimi kültürünün yeterince yaygınlaşmış olmaması, yaşanan ekonomik ve siyasi istikrarsılılılar gibi nedenler, vadeli işlem piyasasındaki işlem hacminin ve yatırımcı sayısının spot piyasaya kıyasla düşük bir seviyede 
kalmasına neden olmaktadır. Dolayısıyla vadeli işlem piyasasının hala gelişme aşamasında olduğu söylenebilir. Söz konusu faktörlerin, vadeli işlem fiyatlarının spot piyasa fiyatları üzerinde öncül bir etkisinin bulunmadığına dair elde edilen sonuçlar üzerinde etkili olabileceği düşünülmektedir. 


\section{REFERENCES}

A kay, H. K and Nargeleçekenler, M. (2006). Finansal Piyasa V olatilitesi ve Ekonomi. Ankara Üniversitesi SBF Dergisi, 61(4), 5-36.

B hamra, H. S. and Uppal, R. (2009). The Effect of Introducing a Non-Redundant Derivative on the $\mathrm{V}$ olatility of Stock-M arket R eturns When A gents Differ in Risk Aversion. The Review of Financial Studies, 22(6), 2303-2330.

Bhar, R. (2001). Return and Volatility Dynamics in the Spot and Futures Markets in A ustralia: An Intervention A nalysis in a Bivariate EGARCH-X Framework. Journal of Futures Markets, 21(9), 833-850.

Bhaumik, S., Karanasos, M. and Kartsaklas, A. (2016). The Informative Role of Trading Volume in an Expanding Spot and Futures M arket. Journal of Multinational Financial Management, 35, 24-40.

Black, F. (1976). Studies in Stock Price Volatility Changes. In Proceedings of the 1976 Meetings of the American Statistical Association, 171-181.

Bodnar, T. and Hautsch, N. (2016). Dynamic Conditional Correlation Multiplicative Error Processes. Journal of Empirical Finance, 36, 41-67.

B ohl, M. T., Diesteldorf, J . and Siklos, P. L. (2015). The Effect of Index Futures Trading on V olatility: Three M arkets for Chinese Stocks. China Economic Review, V ol. 34.

Bollerslev, T. (1990). Modelling the Coherence in Short-Run Nominal Exchange Rates: A M ultivariate Generalized A RCH M odel. Review of Economics and Statistics, 72, 498505.

Bose, S. (2007). Understanding the V olatility Characteristics and Transmission Effects in the Indian Stock Index and Index Futures Market. ICRA Bulletin on Money \& Finance, 139-162.

Corredor, P., Ferrer, E and Santamaria, R. (2015). Sentiment-prone Investors and V olatility Dynamics between Spot and Futures M arkets. International Review of Economics and Finance, 35, 180-196.

Çelik, İ. (2012). Vadeli İşlem Piyasasında Fiyat Keşfi. Türkiye Bankalar Birliği, İstanbul.

Chambers, N. (2009). Türev Piyasalar. Beta Yayınları, 3th Edition, Istanbul.

Chance, D. M. and Brooks, R. (2013). An Introduction to Derivatives and Risk Management. 9th Edition, Cengage Learning, USA.

Changa, C-L., M cA leer, M . and Tansuchat, R. (2013). Conditional Correlations and V olatility Spillovers between Crude Oil and Stock Index Returns. North American Journal of Economics and Finance, 25, 116-138.

Chatrath, A., Christie-David, R., Dhanda, K. K. and Koch, T. W. (2002). Index Futures Leadership, Basis Behavior and Trader Selectivity. The Journal of Futures Markets, 22(7), 649-677.

Chin, K., Chan, K. C. and K arolyi, A . (1991). Intraday V olatility in the Stock Index and Stock Index Futures M arket. The Review of Financial Studies, 4(4), 657-684.

Ching, H. and Hsieh, S. (2014). The Causal Relationships between Stock Returns, Trading V olume and V olatility Empirical Evidence from A sian Listed Real Estate Companies. International Journal of Managerial Finance, 10(2), 218-240.

Christie, A. A. (1982). The Stochastic Behavior of Common Stock Variances: Value, Leverage, and Interest R ate Effect. Journal of Financial Economics, 10(4), 407-432. 
Danielsson, J., Valenzuela, M. and Zer, İ (2016). Learning from History: Volatility and Financial Crises. SRC Discussion Paper, N 0.57, 1-40.

Danthine, J. P. (1976). Information, Futures Prices, and Stabilizing Speculation.' Journal of Economic Theory, 17(1), 79-98.

Charles C. Cox. (1976). Futures Trading and Market Information. Journal of Political Economy, V ol.84, N 0.6, 1215-1237.

Dutta, A . (2014). M odelling V olatility: Symmetric or A symmetric GARCH M odels? Journal of Statistics: Advances in Theory and Applications, 12(2), 99-108.

Enders, W. (2015). Applied Econometric Time Series. Fourth Edition, J ohn W iley\& Sons, Inc., USA.

Engle, R. (2002). Dynamic Conditional Correlation: A Simple Class of Multivariate Generalized Autoregressive Conditional Heteroskedasticity Model. Journal of Business \& Economic Statistics, 20(3), 339-350.

Fan, X. and Du. D. (2017). The spillover effect between CSI 500 index futures market and the spot market. China Finance Review International, 7(2), 249-272.

Ghufran, B., A wan, H. M ., K hakwani, A. K. and Qureshi, M. A . (2016). W hat Causes Stock $M$ arket Volatility in Pakistan? Evidence from the Field. Economics Research International, 2016, 1-9.

Glosten, L.R, Jagannathan, R. and Runkle, D. E. (1993). On the Relation between the Expected Value and the Volatility of the Nominal Excess Return on Stocks. The Journal of Finance, X LV III(5), 1779-1801.

Gök, İ. Y. and Kalaycı, Ş. (2014). BIST 30 Spot ve Futures Piyasalarında Güniçi Fiyat Keşfi ve Volatilite Yay1lımı. Suleyman Demirel University The Journal of Faculty of Economics and Administrative Sciences, 19(3), 109-133.

Gulia, S. (2016). Testing of Relationship Between Trading Volume, Return and V olatility. Amity Global Business Review, 11: 96-102.

Hamilton, J. D. and Gang, L. (1996). Stock market V olatility and the Business Cycle. Journal of Applied Econometrics, 11(5), 573-593.

Hemche, O., Jawadi, F., M aliki, S. B. and Cheffou, A. I. (2016). On the Study of Contagion in the Context of the Subprime Crisis: A Dynamic Conditional Correlation-M ultivariate GARCH A pproach. Economic Modelling, 52, 292-299.

Hinojales, M. and Park, C. Y. (2011). Stock Market Integration: Emerging East Asia's Experience. Devereux, M. B., Lane, P. R., Park, C. Y. and Wei, S. J. (eds.), The Dynamics of Asian Financial Integration. Routledge, Oxon.

Hiraki, T., M aberly, E. D. and Takezawa, N. (1995). The Information Content of end-of-theday Index Futures R eturns: International Evidence From the Osaka N ikkei 225 Futures Contract. Journal of Banking and Finance, 19(5), 921-936.

Hou, Y . and Li, S. (2020). V olatility and skewness spillover between stock index and stock index futures markets during a crash period: New evidence from China. International Review of Economics and Finance, 66, 166-188.

Huo, R. and A hmed, A. D. (2018). Relationships between Chinese stock market and its index futures market: Evaluating the impact of QFII scheme. Research in International Business and Finance, 44, 135-152.

Imegi, J. C. (2014). Impact of Financial Liberalization on Stock M arket V olatility in Nigeria. Journal of Business and Retail Management Research, 8(2), 80-87. 
International Monetary Fund (2003). Financial Asset Price Volatility: A Source Of Instability? Gobal Financial Stability Report: Market Developments and Issues.

James, G. A and Karoglou, M. (2010). Financial Liberalization and Stock M arket V olatility: The Case of Indonesia. Applied Financial Economics, 20, 477-486.

K ang, S. H., Cheong, C. and Y oon, S. M . (2013). Intraday V olatility Spillovers between Spot and Futures Indices: Evidence from the Korean Stock Market. Physica A: Statistical Mechanics and its Applications, 392(8), 1795-1802.

Karabıyık, L and Anbar, A. (2010). Sermaye Piyasası ve Yatırım Analizi. Ekin Kitabevi, Bursa.

Kassimatis, K. (2002). Financial Liberalization and Stock Market Volatility in Selected Developing Countries. Applied Financial Economics, 12, 389-394.

K otkatvuori-Örnberg, J. (2016). Dynamic Conditional Copula Correlation and Optimal Hedge R atios with Currency Futures. International Review of Financial Analysis, 47, 60-69.

Koutmos, G and Tucker, M. (1996). Temporal Relationships and Dynamic Interactions Between Spot and Futures Stock M arkets. The Journal of Futures Markets, 16(1), 5569.

K urz, M ., J in, H. and M otolese, M. (2005). Determinants of Stock M arket V olatility and Risk Premia. Annals of Finance, 1(2), 109-147.

Lafuente-Luengo, J. A. (2009). Intraday Realised V olatility Relationships between the S\&P 500 Spot and Futures M arket. Journal of Derivatives \& Hedge Funds, 15(2), 116-121.

Lin, C. C., - Chen, S-Y., Hwang, D-Y. and Lin, C-F. (2002). Does Index Futures Dominate Index Spot? Evidence from Taiwan Market. Review of Pacific Basin Financial Markets and Policies, 5(2), 255-275.

MacKinnon, J. "Numerical Distribution Functions for Unit Root and Cointegration Tests", Journal of Applied Econometrics, V ol.11, (pp.601-618).

Malhotra, M. and Sharma, D. K. (2016). Volatility Dynamics in Oil and Oilseeds Spot and Futures M arket in India. Vikalpa: The Journal for Decision Makers, 41(2), 132-148.

M athy, G. P. (2016). Stock V olatility, Return J umps and U ncertainty Shocks during the Great Depression. Financial History Review, 23(2), 165-192.

Nelson, D. B. (1996). Modelling Stock Market Volatility Change. Rossi, P. E. (ed.), Modelling Stock Market Volatility, A cademic Press, London, 3-15.

Okur, M. and Çevik, E. (2013). Testing Intraday Volatility Spillovers in Turkish Capital M arkets: Evidence from ISE. Ekonomska Istražıvanja-Economic Research, 26(3), 99116.

Özdemir, L. (2011). Vadeli İşlem Piyasası ile Spot Piyasa Oynaklığı Arasındaki İlişki: İzmir Vadeli İşlem ve Opsiyon Borsası Üzerine Bir Uygulama. Unpublished Doctoral Dissertation, A fyon K ocatepe Üniversitesi Sosyal Bilimler Enstitüsü, A fyon.

Özden, Ü. H. (2008). İMKB Bileşik 100 Endeksi Getiri Volatilitesinin A nalizi. İstanbul Ticaret Üniversitesi Sosyal Bilimler Dergisi, 7(13), 339-350.

P. Sakthivel - B. Kamaiah, (2010). Price Discovery and Volatility Spillover B etween Spot and Futures Markets: Evidence from India. The IUP Journal of Applied Economics, Vol.IX, N 0.2, 81-97.

Pak, Y., Kim, Y -J., Song, M. and Kim, Y -H. (2015). Shock Waves of Political Risk on the Stock M arket: The Case of Korean Companies in the U.S. Development and Society, 44(1), 143-165. 
Pati, P. C. and Rajib, P. (2011). Intraday Return Dynamics and V olatility Spillovers between NSE S\&P CNX Nifty Stock Index and Stock Index Futures. Applied Economics Letters, 18(6), 567-574.

Patra, G. C. and M ohapatra, S. R. (2011). A Testing of Lead-lag Relationship between Nifty Spot and Futures Index Returns and V olatility. International Journal of Financial Management, 1(4), 13-22.

Paul, M. T. and Kimata, J. D. (2016). The Linkages, Persistence, Asymmetry in The Volatility, The Price Discovery and Efficiency and The Effect of The US Subprime Mortgage Financial Crisis on The Spot and The Futures Market's Returns: The Case of India. Applied Economics, 48(8), 669-683.

Sadiq, M., A hmad, S., A njum, M. J., Suliman, M., A brar, S-U. and K han, S-U-R. (2013). Stock Price V olatility in Relation to Dividend Policy: A Case Study of Karachi Stock M arket. Middle-East Journal of Scientific Research, 13(3), 426-431.

Schwert, G. W. (1989). W hy Does Stock M arket V olatility Change Over Time? The Journal of Finance, X LIV (5), 1115-1153.

Sehgal, S. and Dutt, M. (2016). Domestic and International Information Linkages between NSE Nifty Spot and Futures M arkets: An Empirical Study for India. Decision, 437(3), 239-258.

Tokat, E. and Tokat, H. A . (2010). Shock and Volatility Transmission in the Futures and Spot M arkets: Evidence from Turkish M arkets. Emerging Markets Finance \& Trade, 46(4), 92-104.

Tse, Y. (1999), "Price Discovery and Volatility Spillovers in the DJIA Index and Futures M arkets. The Journal of Futures Markets, 19(8), 911-930.

Wang, K-L. and Chen, M-L. (2007). The Dynamics in the Spot, Futures, and Call Options with Basis Asymmetries: An Intraday Analysis in a Generalized Multivariate GARCH-M MSKST Framework. Review of Quantitative Finance and Accounting, 29(4), 371-394.

Wang, Y - C. and Ho, W-R (2010). The Relationship of Price Volatility between TSE and TAIFEX Stock Indices Futures with Different M aturities. African Journal of Business Management, 4(17), 3785-3792.

Wang, Y $-H$. and Lin, C-T. (2008). Empirical A nalysis of Political Uncertainty on TAIEX Stock M arket. Applied Economics Letters, 15, 545-550.

Xie, S. and Huang, J. (2014). The Impact of Index Futures on Spot Market V olatility in China. Emerging Markets Finance \& Trade, 50, 167-177.

Y ang, J., Y ang, Z. and Zhou, Y . (2012). Intraday Price Discovery and V olatility Transmission in Stock Index and Stock Index Futures M arkets: Evidence from China. The Journal of Futures Markets, 32(2), 99-121.

Zhou, B. and W u, C. (2016). Intraday Dynamic Relationships B etween CSI 300 Index Futures and Spot M arkets: A High-Frequency A nalysis. Neural Comput \& Applic, 27, 10071017.

Zhou, Z., D ong, H. and W ang, S. (2014). Intraday V olatility Spillovers between Index Futures and Spot M arket: Evidence from China. Procedia Computer Science, 31, 721-730. 


\begin{tabular}{|c|c|c|}
\hline $\begin{array}{l}\text { KATKI ORANI / } \\
\text { CONTRUBUTION } \\
\text { RATE }\end{array}$ & AÇIKLAMA / EXPLANATION & $\begin{array}{c}\text { KATKIDA } \\
\text { BULUNANLAR / } \\
\text { CONTRIBUTORS }\end{array}$ \\
\hline $\begin{array}{c}\text { Fikir veya K avram / Idea } \\
\text { or Notion }\end{array}$ & $\begin{array}{c}\text { Araştırma hipotezini veya fikrini } \\
\text { oluşturmak / Form the research } \\
\text { hypothesis or idea }\end{array}$ & $\begin{array}{c}\text { Esen KARA } \\
\text { A dem ANBAR }\end{array}$ \\
\hline Tasarım / Design & $\begin{array}{c}\text { Yöntemi, ölçeği ve deseni } \\
\text { tasarlamak / Designing method, } \\
\text { scale and pattern }\end{array}$ & $\begin{array}{c}\text { Esen KARA } \\
\text { Özer ARABACI }\end{array}$ \\
\hline $\begin{array}{c}\text { Veri Toplama ve İşleme / } \\
\text { Data Collecting and } \\
\text { Processing } \\
\end{array}$ & $\begin{array}{c}\text { Verileri toplamak, düzenlemek ve } \\
\text { raporlamak / Collecting, organizing } \\
\text { and reporting data }\end{array}$ & $\begin{array}{c}\text { Esen KARA } \\
\text { Özer ARABACl }\end{array}$ \\
\hline $\begin{array}{l}\text { Tartışma ve Yorum / } \\
\text { Discussion and } \\
\text { Interpretation }\end{array}$ & $\begin{array}{c}\text { Bulguların değerlendirilmesinde ve } \\
\text { sonuçlandırılmasında sorumluluk } \\
\text { almak / Taking responsibility } \\
\text { in evaluating and finalizing the } \\
\text { findings }\end{array}$ & $\begin{array}{c}\text { Esen KARA } \\
\text { A dem ANBAR }\end{array}$ \\
\hline $\begin{array}{l}\text { Literatür Taramas1 / } \\
\text { Literature Review }\end{array}$ & $\begin{array}{c}\text { Çalışma için gerekli literatürü } \\
\text { taramak / Review the literature } \\
\text { required for the study }\end{array}$ & Esen KARA \\
\hline
\end{tabular}

